\title{
Wanita Pencari Nafkah dalam Pandangan Ulama Pedesaan
}

\author{
Ila Nurmila \\ Institut Agama Islam Darussalam (IAID) Ciamis, Jawa Barat \\ Email: zaki.abdulwahab12@gmail.com \\ Zaki Abdul Wahab \\ Institut Agama Islam Darussalam (IAID) Ciamis, Jawa Barat \\ Miftah Farid \\ Institut Agama Islam Darussalam (IAID) Ciamis, Jawa Barat
}

\begin{abstract}
ABSTRAK
Pernikahan merupakan ibadah yang penting. Bahkan pernikahan merupakan bagian dari kesempurnaan dalam beragama. Prosesi ini adalah hal yang sakral. Setiap orang yang melakukan pernikahan harus memenuhi rukun dan syarat perkawinan, yang menyebabkan timbulnya hak dan kewajiban bagi keduanya. Kewajiban bagi seorang suami, maupun istri berbeda-beda sesuai dengan kemampuannya. Akibat hukum dari suatu perkawinan yang sah antara lain: timbul hak-hak antara suami istri, suami menjadi kepala rumah tangga dan istri menjadi ibu rumah tangga. Timbul pula kewajiban suami untuk membiayai dan mendidik anak-anak dan istrinya, serta mengusahakan tempat tinggal bersama kewajiban suami yang berkenaan dengan kebutuhan hidup tidak hanya memberi nafkah saja. kewajiban suami juga menyediakan tempat tinggal, biaya rumah tangga seperti kebutuhan listrik, air dan lainnya, sampai biaya perawatan bagi istri dan anak jika mengalami sakit.
\end{abstract}

\section{ABSTRACT}

Marriage is an important worship. Even marriage is a part of perfection in religion. This procession is a sacred thing. Everyone who does marriage must meet the pillars and marital requirements, which leads to the rights and obligations of both. The duty of a husband, as well as a wife varies according to his ability. The legal consequences of a legal marriage include: arising rights between husband and wife, husband becoming head of household and wife becoming housewife. Also arise the obligation of the husband to finance and educate the children and his wife, and seek a place to live with the obligation of the husband with regard to the necessities of life not only provide a living alone. the obligation of the husband also 
provides shelter, household expenses such as electricity, water and other needs, to the cost of care for the wife and children if they are sick.

Keywords: Marriage, Rights and Obligations, Livelihood

\section{PENDAHULUAN}

Menikah merupakan amalan yang disyari'atkan di dalam Islam, karena pernikahan merupakan sarana untuk mendapatkan ketenangan, memperbanyak jumlah umat dan pintu berbagai jenis kebaikan, serta untuk menjaga diri dari berbuat zina.

Tujuan perkawinan secara tegas telah dicanangkan dalam regulasi kehidupan berbangsa dan bernegara. Undang-undang No. 1 Tahun 1974, misalnya, menyatakan bahwa: "Perkawinan ialah ikatan lahir batin antara seorang pria dan wanita sebagai suami istri dengan tujuan membentuk keluarga (rumah tangga) yang bahagia dan kekal berdasarkan ketuhanan Yang Maha Esa" (Anonimous, 2010:284).

Setiap orang yang menikah mempunyai maksud untuk mewujudkan kehidupan rumah tangga yang sakinah, mawaddah, dan rahmah. Hal ini membentuk keluarga yang tentram, aman, damai, penuh kasih sayang dan rahmat dari Allah SWT. Sebagaimana dalam firman Allah, "Dan diantara tanda-tanda kekuasaan-Nya ialah Dia menciptakan untukmu istri-istri dari jenismu sendiri, supaya kamu cenderung dan merasa tenteram kepadanya, dan dijadikan-Nya di antaramu rasa kasih dan sayang. Sesungguhnya pada yang demikian itu benar-benar terdapat tanda-tanda bagi kaum yang berpikir (Q.S. Ar-Ruum, 30:21).

Ketentraman yang dimaksud dalam ayat ini bukanlah sekedar dari ketentraman syahwat, tetapi ketentraman yang datang dari jiwa seseorang. Ketenangan rohani merupakan puncak dari kenikmatan. Hubungan suami istri lebih kepada untuk mencari ketentraman jiwa. Seperti halnya Rasullullah ketika mendapatkan wahyu pertama kali, Khadijahlah sebagai seorang istri yang dapat menentramkan hati Rasulullah saw (Mahalli, tt:14).

Pernikahan merupakan ibadah yang penting. Bahkan pernikahan merupakan bagian dari kesempurnaan dalam beragama. Prosesi ini adalah hal yang sakral. Setiap orang yang melakukan pernikahan harus memenuhi rukun dan syarat perkawinan, yang menyebabkan timbulnya hak dan kewajiban bagi keduanya. Kewajiban bagi seorang suami, maupun istri berbeda-beda sesuai dengan kemampuannya. Akibat hukum dari suatu perkawinan yang sah antara lain: timbul hak-hak antara suami istri, suami menjadi kepala rumah tangga dan istri menjadi ibu rumah tangga. Timbul pula kewajiban suami untuk membiayai dan mendidik anak-anak dan istrinya, serta mengusahakan tempat tinggal bersama (Ramulyo, 2004:248). 
Membina sebuah rumah tangga bukan hanya untuk saling menguasai dan memiliki antara satu pihak dengan pihak yang lain. Di dalamnya terdapat banyak tugas dan kewajiban yang besar bagi kedua belah pihak termasuk tanggung jawab ekonomi. Nafkah merupakan satu hak yang wajib dipenuhi oleh seorang suami terhadap istrinya, nafkah ini bermacammacam, bisa berupa makanan, tempat tinggal, pelajaran (perhatian), pengobatan, dan juga pakaian. Sebagaimana dalam sabda Nabi Muhammad>

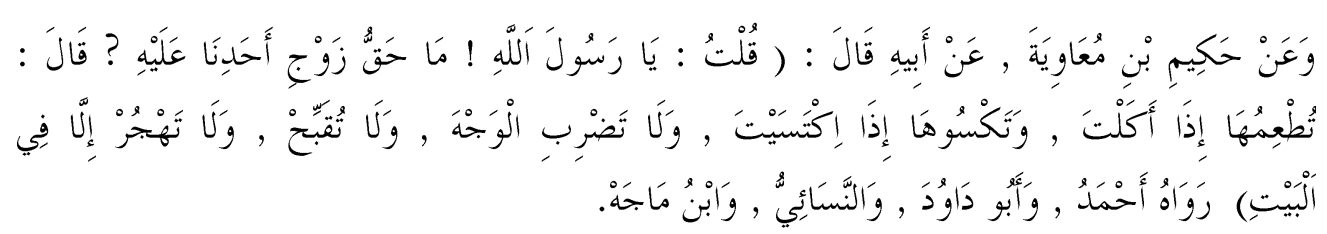

Dari Hakim putra Muawiyah dari ayahnya ra., ia berkata: Aku bertanya: ya, Rasulullah, apa kewajiban seorang diantara kami terhadap isteri?" beliau menjawab: kamu beri makan bila kamu makan, kamu beri, pakaian bila kamu berpakaian, janganlah kamu memukul dan janganlah kamu mencela dan janganlah kamu tinggalkan kecuali di dalam rumah (Diriwayatkan oleh Imam Ahmad, Imam Abu Daud Imam Nasa'i, dan Imam ibnu majjah), (al-Asqolani, tt: 220).

Hadits di atas menjelaskan bahwa kewajiban seorang suami adalah memberi makan dan pakaian (nafkah) kepada istri, serta bersikap baik kepadanya. Untuk dapat memberi nafkah seorang harus mampu secara ekonomi. Oleh karena itu Rasullullah saw juga memerintahkan hanya pemuda yang mampu yang disuruh untuk menikah. Sebagaimana dalam hadits berikut :

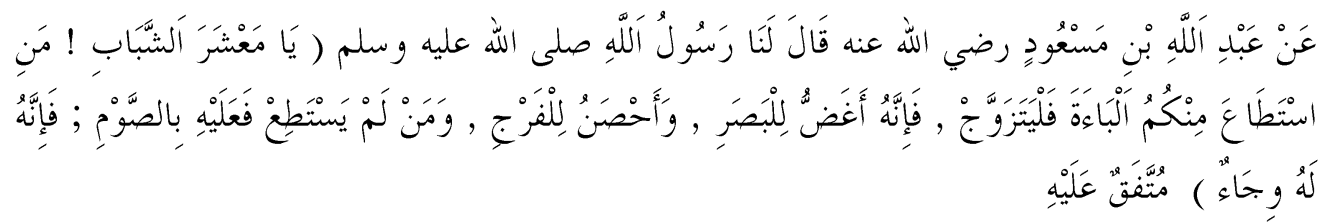

Abdullah Ibnu Mas'ud Radliyallaahu 'anhu berkata: Rasulullah Shallallaahu 'alaihi wa Sallam bersabda pada kami: Wahai para pemuda, barangsiapa di antara kalian telah mampu serta berkeinginan untuk menikah, maka hendaklah ia menikah. Karena sesungguhnya pernikahan itu dapat menundukkan pandangan dan memelihara kemaluan. Dan barangsiapa tidak mampu, maka hendaklah ia berpuasa, karena sesungguhnya puasa itu dapat menjadi tameng baginya (melemahkan syahwat), (H.R. Muttafaq 'alaih) (al-Asqolani, tt: 208).

Penjelasan hadist tersebut adalah bahwa pemuda yang mampu dan mempunyai keinginan untuk menikah sebaiknya menikah, karena 
pernikahan dapat menjaga diri dari kemaksiatan. Bagi pemuda yang belum menikah sebaiknya berpuasa, karena puasa dapat melatih menahan diri dari segala hawa nafsu. Dari hadits di atas juga dapat diambil kesimpulan bahwa laki-laki setelah menikah akan menanggung kewajiban memberi nafkah kepada keluarga. Sehingga Rasulullah memberi perintah menikah hanya kepada pemuda yang telah mampu.

Kewajiban memberi nafkah bagi Istri oleh suami juga diatur dalam Kompilasi Hukum Islam pasal 80 poin ke-4 yang berbunyi: "Sesuai dengan penghasilannya suami menanggung: a. nafkah, kiswah dan tempat kediaman bagi isteri; $b$. biaya rumah tangga, biaya perawatan dan biaya pengobatan bagi isteri dan anak; c. biaya pendidikan bagi anak" (Anonimous, 2010:220).

Dalam pasal selanjunya di jelaskan: "suami terhadap Istri seperti tersebut pada ayat (4) huruf a dan b di atas mulai berlaku sesudah ada tamkin sempurna dari istrinya" (Anonimous, 2010:221).

Pasal di atas kewajiban suami yang berkenaan dengan kebutuhan hidup tidak hanya memberi nafkah saja. kewajiban suami juga menyediakan tempat tinggal, biaya rumah tangga seperti kebutuhan listrik, air dan lainnya, sampai biaya perawatan bagi istri dan anak jika mengalami sakit. Nafkah wajib ini semata karena adanya akad yang sah, penyerahan diri istri kepada suami, memungkinkannya suami menikmati dirinya, tidak menolak apabila diajak pindah ketempat yang dikehendaki suami, dan keduanya bisa saling menikmati (Sabiq, 1981:80).

Seorang laki-laki begitu banyak tanggung jawabnya, karena seorang laki-laki adalah pemimpin bagi kaum wanita. Sebagaimana firman Allah dalam ayat, "Kaum laki-laki itu adalah pemimpin bagi kaum wanita, oleh karena Allah telah melebihkan sebahagian mereka (laki-laki) atas sebagian yang lain (wanita), dan karena mereka (laki-laki) telah menafkahkan sebagian dari harta mereka. Sebab itu maka wanita yang saleh, ialah yang taat kepada Allah lagi memelihara diri ketika suaminya tidak ada, karena Allah telah memelihara (mereka) (Q.S. An-Nisa, 4:84).

Ayat di atas menerangkan bahwa suami adalah pemimpin bagi wanita, karena seseorang laki-laki mempunyai kelebihan dari pada wanita. Hal ini karena, seorang laki-laki mempunyai kewajiban memberikan nafkah dari harta yang mereka miliki kepada keluarganya (Fillah, 2006:20).

Berdasarkan paparan tersebut adalah suami yang diwajibkan menanggung beban ekonomi keluarga. Namun dewasa ini hampir di setiap profesi terdapat wanita di dalamnya yang bekerja. Dari pemulung, pendidik, petani, bahkan presiden juga di jabat oleh seorang perempuan.

Allah juga memerintahkan wanita untuk tetap tinggal di dalam rumah dan tidak berhias ketika keluar rumah. Sebagaimana Allah berfirman dalam 
al-Qur'an, "Dan hendaklah kamu tetap di rumahmu dan janganlah kamu berhias dan bertingkah laku seperti orang-orang Jahiliyah (Q.S Al-Ahzab, 33:423).

Ayat di atas menyaran seseorang untuk tetap tinggal di rumah, melarang untuk berhias ketika keluar rumah, serta tidak bertingkah laku seperti orang jahiliyah.

Namun realitas dilapangan yang terjadi di Desa Karangampel Kecamatan Baregbeg Kabupaten Ciamis dijumpai suatu realita bahwa mayoritas wanita di desa tersebut bekerja di pabrik, sehingga terjadi suatu fenomena bahwa seorang isteri yang justru menanggung beban nafkah untuk suami anaknya, sedangkan suami bertugas mengurus rumah tangga.

Di Indonesia telah banyak dimulai penelitian yang mempromosikan tentang peran produktif perempuan. Menurut Sumadi (2017) bahwa penelitian tentang perempuan "promotion of women's productive role. Although normatively positive law and women's ethics have subordinate positions, in reality, women occupy productive roles, starting from their own households to broader public roles".

Berdasarkan permasalahan di atas, maka perlu untuk dibahas secara mendalam mengenai peran publik perempuan terkait dengan perempuan pencari nafkah di pedesaaan.

\section{KAJIAN TEORITIK}

\section{Konsep Nafkah}

Kata nafkah yang berasal dari kata أَنْفَ dalam bahasa Arab secara فنى yang berarti kurang. Juga berarti نقص و قل etimologi mengandung arti yang berarti berkurang. Juga memberikah nafkah membuat harta yang dimilikinya menjadi sedikit karena telah dilenyapkannya atau dibagikannya untuk kepentingan orang lain. Bila kata ini dihubungkan dengan perkawinan mengandung arti "sesuatu yang dikeluarkannya dari hartanya untuk kepentingan istrinya sehingga menyebabkan hartanya menjadi berkurang". Dengan demikian, nafkah istri berarti pemberian yang wajib dilakukan oleh suami terhadap istrinya dalam masa perkawinannya (Syarifuddin, 2009: 165).

Nafkah merupakan kewajiban suami terhadap istrinya dalam bentuk materi, karena kata nafkah itu sendiri berkonotasi materi. Sedangkan kewajiban dalam bentuk nonmateri, seperti memuaskan seksual istri tidak termasuk dalam arti nafkah meskipun dilakukan suami terhadap istrinya. Yang termasuk dalam pengertian nafkah menurut kesepakatan ulama adalah belanja untuk keperluan makan yang mencakup Sembilan bahan 
pokok, pakaian dan perumahan atau kebutuhan sandang, pangan dan papan (Syarifuddin, 2009: 165).

Nafkah adalah semua kebutuhan dan keperluan yang berlaku menurut keadaan dan tempat, seperti makanan, pakaian, rumah, dan sebagainya. Banyaknya nafkah yang diwajibkan adalah sekedar mencukupi keperluan dan kebutuhan serta mengingat keadaan dan kemampuan orang yang berkewajiban menurut kebiasaan masing-masing tempat (Rasjid, 2013: 421). Firman Allah, "Hendaklah orang yang mampu memberi nafkah menurut kemampuannya. (At-Thalaq, 65: 7).

a. Sebab-sebab Diwajibkannya Nafkah

Kewajiban nafkah tersebut dipengaruhi oleh tiga sebab: (1) Zaujiyyah yaitu karena ikatan pernikahan yang sah, diwajibkan atas suami memberi belanja kepada istrinya yang ta'at (tidak Nusyuz), baik berupa makanan , pakaian, tempat tinggal maupun perkakas rumah tangga dan kebutuhan lainnya sesuai dengan masing-masing lingkungan dan kekuatan Suami (Basjid, 1976: 399). (2) Qarabah yaitu sebab hubungan kekerabatan. (3) Milk yaitu sebab kepemilikan atas sesuatu, dalam hal ini pemilik budak. Dalam konteks kekinian, sebab milk ini dapat dipahami dalam konteks yang luas, yaitu hubungan kepemilikan (kegiatan berorientasi tanggungan/ihtibas) seseorang terhadap sesuatu yang hidup, termasuk jasa pembantu, memelihara hewan, tumbuhan dan lain-lain.

b. Bentuk-bentuk Nafkah

Bentuk-bentuk nafkah ini telah dijelaskan dalam kewajiban seorang suami beserta dengan sebagai dasarnya baik berupa ayat al-Quran maupun Undang-Undang. Para ulama fiqih menyimpulkan bahwa nafkah yang wajib diberikan suami kepada isterinya, meliputi; makanan, miniman, laukpauk, pakaian, tempat tinggal, pembantu (jika diperlukan), alat-alat pembersih tubuh dan perabot rumah tangga (Muhammad, 2001: 123).

Sementara nafkah untuk alat-alat kecantikan bukan merupakan kewajiban suami. Kecuali sebatas untuk menghilangkan bau badan istri. Hal ini selaras dengan pendapat imam Nawawi dari Madzhab Syafi'i yang menyatakan bahwa suami tidak berkewajiban memberikan nafkah untuk biaya alat kecantikan mata, kuteks, minyak wangi, dan alat-alat kecantikan lainnya yang semuanya dimaksudkan untuk menambah gairah seksual (Muhammad, 2001:123-124)

Berlanjut pada nafkah kesehatan. suami tidak berkewajiban untuk memberikan nafkah kesehatan, baik untuk membeli obat-obatan maupun biaya ke dokter. Namun hal ini di tentang oleh Wahbah az-Zuhaili, Pemikir fiqih kontemporer. Pada masa sekarang kebutuhan akan kesehatan menjadi pokok sama seperti makanan, tidak seperti kebutuhan akan kesehatan pada 
masa dahulu, sehingga nafkah kesehatan menjadi wajib (Muhammad, 2001: 124-125).

c. Kadar Nafkah yang Harus Diberikan oleh Suami

Menurut imam Syafi'i ukuran nafkah bagi orang miskin dan orang yang berada dalam kesulitan adalah satu mud. Bagi orang yang berada dalam kemudahan adalah dua mud. Jika diantara keduanya adalah satu setengah mud.

Sedangkan menurut Abu Hanifah bagi orang yang dalam kemudahan memberikan tujuh sampai delapan dirham tiap bulannya, sedangkan orang yang empat sampai lima dirham setiap bulannya. dalam kesulitan memberikan.

Namun sebagian ulama berpendapat bahwa tidak ada ukuran tertentu dalam memberikan nafkah. Hal ini disebabkan adanya perbedaan waktu, tempat, keadaan dan kebutuhan dari setiap individu (Uwaidah, 2006: 453). Sebagaimana dalam Hadits berikut:

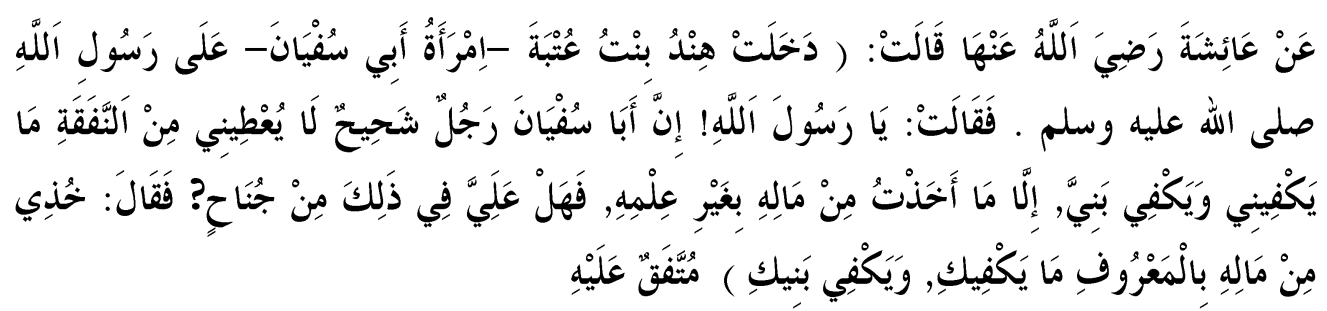

'Aisyah Radliyallaahu 'anhu berkata: Hindun binti Utbah istri Abu Sufyan masuk menemui Rasulullah Shallallaahu 'alaihi wa Sallam dan berkata: Wahai Rasulullah, sungguh Abu Sufyan adalah orang yang pelit. Ia tidak memberiku nafkah yang cukup untukku dan anak-anakku kecuali aku mengambil dari hartanya tanpa sepengetahuannya. Apakah yang demikian itu aku berdosa? Beliau bersabda: "Ambillah dari hartanya yang cukup untukmu dan anak-anakmu dengan baik." Muttafaq Alaihi. (al-Asqalani, tt:249).

Hadits tersebut jelas menyatakan bahwa tidak ada ukuran nafkah tertentu dengan menekankan kata "secukupnya", secukupnya menunjukkan nafkah yang relatif bagi setiap orang. Jika kewajiban nafkah mempunyai batasan dan ukuran tertentu Rasulullah saw akan memerintahkan Hindun untuk mengambil ukuran nafkah yang dimaksud, tetapi pada saat itu Rasulullah hanya memerintahkan Hindun untuk mengambil sebagian harta suaminya dengan cara baik dan secukupnya.

Seorang suami dalam menafkahkan hartanya selain tidak boleh terlalu bakhil, suami juga tidak boleh terlalu boros dalam menafkahkan hartanya. Dalam menafkahkan harta harus berpegang teguh kepada tuntunan Allah (Mujab, 2008: 265). Sebagaimana dalam firman Allah, "“Dan 
orang-orang yang apabila membelanjakan (harta), mereka tidak berlebihlebihan, dan tidak (pula) kikir, dan adalah (pembelanjaan itu) di tengahtengah antara yang demikian". (Q.S Al-Furqaan, 25: 67)

Pendapat golongan Syafi'i dan sebagian besar golongan Hanafi bahwa ketika menetapkan jumlah nafkah harus memperhatikan kemampuan suami.

Pendapat inilah yang sekarang diikuti oleh pengadilan Mesir, sebagaimana yang disebutkan dalam pasal 16 Undang-Undang No. 25 tahun 1929, yang berbunyi; "Penetapan nafkah bagi isteri oleh suaminya disesuaikan dengan keadaan kaya dan miskinnya suami tanpa melihat bagaimana keadaan isteri." (Sabiq, 1981:92).

d. Waktu Wajib Nafkah

Menurut Ibnu Hazm suami suami berkewajiban menafkahi isterinya sejak terjadinya akad nikah, baik suami yang mengajaknya hidup serumah atau tidak, baik isteri masih dalam buaian atau berbuat nusyuz, kaya atau kafir, mempunyai orang tua atau sudah yatim, gadis atau janda, semua itu disesuaikan dengan keadaan dan kesanggupan suami (Sabiq, 1981:85).

Konsep Hak dan Kewajiban

a. Kewajiban suami terhadap istri

1) Maskawin atau mahar

Maskawin atau mahar adalah pemberian seorang suami kepada istrinya sebelum, sesudah atau pada waktu berlangsungnya akad sebagai pemberian wajib yang tidak dapat diganti dengan yang lain. Mahar juga merupakan hak istri sepenuhnya, dan karena itu suami tidak diperbolehkan untuk menunda-nundanya, jika dia memintanya, atau diminta dikembalikan darinya, baik secara keseluruhannya maupun sebagian setelah diberikan kepadanya (Sabiq, 1981:433).

Allah berfirman dalam Q.S. An-Nisa (4) ayat 4, "Berikanlah maskawin (mahar) kepada wanita (yang kamu nikahi) sebagai pemberian dengan penuh kerelaan. kemudian jika mereka menyerahkan kepada kamu sebagian dari maskawin itu dengan senang hati, Maka makanlah (ambillah) pemberian itu (sebagai makanan) yang sedap lagi baik akibatnya (Q.S. AnNisa, 04: 04).

Syariat Islam tidak membatasi kadar maskawin yang diberikan suami kepada istrinya. Agama menyerahkannya kepada masyarakat untuk menetapkannya menurut adat yang berlaku dikalangan mereka menurut kemampuannya. Nash al-Qur'an dan hadits hanya menetapkan bahwa maskawin itu harus berbentuk dan bermanfaat tanpa melihat sedikit atau banyaknya (Alhamdani, 1985: 110).

2) Memberikan nafkah 
Diantara hak istri adalah diberi nafkah. Istri dan anak-anak mempunyai hak untuk mendapatkan nafkah yang tidak berlebihan dan tidak pula terlalu kikir.

Allah berfirman dalam surah Al-Baqarah ayat 233, "Dan kewajiban ayah memberi makan dan pakaian kepada para ibu dengan cara ma'ruf. Seseorang tidak dibebani melainkan menurut kadar kesanggupannya (Q.S. Al-Baqarah, 02: 233).

Nafkah tersebut tidak cukup berupa makanan dan minuman saja, tetapi mencakup tempat tinggal, makanan dan pakaian (Usamah, 2006: 341). Arti kata seseorang tidak dibeban melainkan menurut kadar kesanggupannya, dalam Tafsir Fi Zhilalil Qur'an dijelaskan bahwa hal tersebut mengandung makna jangan sampai salah seorang dari kedua orang tua itu menjadikan anak sebagai kemadharatan yang satunya. Maka jangan seorang ayah mengeksploitasi kasih sayang ibu terhadap anaknya untuk berlaku sewenang-wenang terhadapnya, atau agar si ibu menyusui anaknya dengan tidak diberinya imbalan. Apabila si ayah meninggal dunia, kewajibankewajibannya pindah kepada ahli warisnya. Ahli waris diberi tugas untuk memberi sandang dan pangan kepada ibu yang menyusui itu secara ma'ruf dan baik sebagai realisasi solidaritas keluarga yang diantaranya terwujud dalam bentuk pewarisan. Dengan demikian, tidak terabaikanlah anak karena kematian ayahnya. Maka haknya dan hak ibunya dalam semua keadaan tetap terjamin (Quthb, 2000: 302).

3) Menggauli istri secara baik dan patut

Kewajiban pertama seorang suami terhadap istrinya adalah memuliakan dan mempergaulinya dengan baik, menyediakan apa yang dapat disediakan untuk istrinya yang akan dapat mengikat hatinya, memperhatikan dan bersabar apabila ada yang tidak berkenan dihatinya (Alhamdani, 1985: 136).

Allah berfirman dalam surat An-Nisa ayat 19, "Dan bergaullah dengan mereka secara patut. Kemudian bila kamu tidak menyukai mereka, (maka bersabarlah) karena mungkin kamu tidak menyukai sesuatu, Padahal Allah menjadikan padanya kebaikan yang banyak. (Q.S. An-Nisa, 04 : 19).

Dalam menafsirkan ayat tersebut di atas, Ibnu Katsir mengatakan: yakni perbaguslah ucapan kalian kepada mereka, dan perbaguslah perbuatan kalian dan keadaan kalian sesuai kemampuan kalian, sebagaimana kalian menyukai hal itudari mereka. Oleh karena itu, lakukanlah hal yang sama terhdap mereka. Sedangkan Al-Qurthubi berkata bahwa mempergauli mereka dengan baik merupakan perintah yang berlaku bagi kedua belah pihak, sebab masing-masing berhak mendapat perlakuan yang baik, baik suami maupun istri. Akan tetapi, yang dikehendaki dari perintah ini secara umum adalah para suami (Usamah, 2006: 330). 
4) Menjaga istri

Disamping berkewajiban mempergauli istri dengan baik, maka suami juga wajib menjaga martabat dan kehormatan istrinya, mencegah istrinya jangan sampai hina, jangan sampai istrinya berkata jelek.

Allah berfirman dalam surat At-Tahrim ayat 6, "Hai orang-orang yang beriman, peliharalah dirimu dan keluargamu dari api neraka yang bahan bakarnya adalah manusia dan batu; penjaganya malaikat-malaikat yang kasar, keras, dan tidak mendurhakai Allah terhadap apa yang diperintahkan-Nya kepada mereka dan selalu mengerjakan apa yang diperintahkan (Q.S. At-Tahrim, 66: 06).

b. Kewajiban Istri Terhadap Suami

Kewajiban istri terhadap suaminya tidak ada yang berbentuk materi. Melainkan hanya kewajiban dalam bentuk nonmateri. Suami mempunyai beberapa hak yang menjadi kewajiban istri terhadap suaminya (Syarifuddin, 2008:162), diantaranya adalah: 1) Menggauli suami secara layak sesuai dengan kodratnya 2) Memberikan rasa tenang dalam rumah tangga untuk suaminya, dan memberi rasa cinta dan kasih sayang dalam batas kemampuannya 3) Taat dan patuh kepada suami selama suaminya tidak menyuruh untuk melakukan perbuatan maksiat 4) Menjaga dirinya dan harta suaminya a pabila suami sedang tidak berada di rumah 5) Menjauhkan dirinya dari segala perbuatan yang tidak disenangi oleh suaminya 6) Menjauhkan dirinya dari memperlihatkan wajah yang tidak enak dipandang dan suara yang tidak enak didengar.

c. Syarat-syarat Kepemilikan Hak terhadap Nafkah

Syariat mewajibkan suami memberi nafkah kepada istri karena berdasarkan beberapa syarat yang harus dipenuhi, yaitu:

1) Akad nikah dilaksanakan secara sah.

2) Istri menyediakan diri bagi suami untuk menikmati kesenangan dengan dirinya.

3) Istri tidak menolak untuk pindah sesuai dengan keinginan suami, kecuali jika suami menginginkan hal yang membahayakan dalam perjalanan atau tidak dapat memberi rasa aman kepada diri atau hartanya.

4) Kedua suami istri masih mampu melaksanakan kewajiban sebagai suami istri (Sabiq, 1981:429).

\section{METODE PENELITIAN}

Metode yang digunakan adalah metode kualitatif berdasarkan analisis data yang bersifat deskriptif, penelitian deskriptif bertujuan untuk mendepenelitiankan apa-apa yang saat ini berlaku. Sedangkan teknik 
pengumpulan data dilakukan dengan menggali data dari kepustakaan. Data-data yang terkumpul kemudian dianalisis dengan teknik analisis data. (LPP, 2001: 20).

\section{HASIL PENELITIAN DANPEMBAHASAN}

Kondisi objektif Desa Karangampel

Sebelum penulis menguraikan intisari dari permasalahan pendapat ulama dalam pengambilan kewajiban memberi nafkah suami oleh istri, maka perlu penjelasan kondisi Desa Karangampel Kecamatan Baregbeg Kabupaten Ciamis, baik dari segi geografis, demografis, penghasilan maupun dari segi kehidupan agamanya. Karena seorang peneliti yang tidak mengetahui dan mengenal suatu daerah yang menjadi objeknya, akan memusatkan data-data yang kurang aktual, pada akhirnya akan mendapatkan data yang kurang objektif dan kurang memuaskan, dengan kata lain penarikan kesimpulan harus diadakan sesuai dengan data yang ada tidak didasarkan pada angan-angan saja.

Adapun luas wilayah yan terdapat di Desa Karangampel Kecamatan Baregbeg Kabupaten Ciamis adalah 531.754 Ha. Dan dari sekian luasnya Desa Karangampel terdiri dari empat dusun: Dusun Babakan, Dusun Barugbug, Dusun Kidul, dan Dusun Kaler.

Penduduk Desa Karangampel merupakan penduduk yang mayoritas beragama Islam. Untuk masa sekarang Desa Karangampel penuh menjalankan ajarannya terutama dalam bidang shalat dan puasa. Terbukti dengan adanya sarana dan pra sarana ibadah seperti masjid, madrasah dan sekolah. Hal ini menunjukan bahwa perkembangan Islam di Desa Karangampel cukup baik.

Sejalannya ulama dengan umaro di Desa Karangampel dalam menata ketertiban dan keamanan dilinkungan Karangampel, hal ini menunjukan bahwa keadaan Desa Karangampel adanya jalinan persatuan dan kesatuan umat. Terlebih usaha para ulama dalam mengentaskan beberapa permasalahan keagamaan yang timbul di Desa Karangampel.

Adanya kegiatan para ulama di daerah masing-masing akhirnya mereka (ulama) bisa mempengaruhi mereka yang masih muda atau para orang tua dengan jalan pengadaan pengajian-pengajian di lingkungan RT (rukun tetangga) dan di dusun-dusun, dan hampir setiap hari terisi.

Bukan saja pengajian orang tua dalam majlis-majlis ta'lim yang aktif pengajian tetapi yang lebih menjadi kebanggaan adalah kesadaran para pemuda-pemudi dalam mempelajari masalah keagamaan dengan mengadakan acara pengajian rutinitas mingguan khusus pemuda-pemudi dalam rangka pembinaan mental spiritual untuk menjaga terjadinya hal-hal 
yang tidak diinginkan oleh masyarakat. Hal ini menunjukan bahwa kehidupan keagamaan di Desa Karangampel Meningkat.

Pendapat Ulama Desa Karangampel tentang Wanita sebagai Pencari Nafkah Utama dalam Kehidupan Rumah Tangga

Hasil wawncara dengan sebagian ulama Desa Karangampel antara lain Bapak K.H Hasan (Disamping sebagai tokoh masyarakat yang sering memberikan tausiyah di majlis ta'lim ia juga sebagai pimpinan pondok pesantren Darul Falah), mengatakan jika seorang istri bekerja mencari nafkah sementara suami pengangguran, maka hal itu telah menyalahi nash al-Qur'an sebagaimana firman Allah, "Kaum laki-laki itu adalah pemimpin bagi kaum wanita, oleh karena Allah telah melebihkan sebahagian mereka (laki-laki) atas sebahagian yang lain (wanita), dan karena mereka (laki-laki) telah menafkahkan sebahagian dari harta mereka (Q.S An-Nisa, 4:34).

Menurut K.H Hasan penafsiran dari ayat tersebut adalah kenapa lakilaki disebut sebagi pemimpin? "Pertama, karena suami wajib memberikan mahar terhadap istri. Kedua karena suami wajib memberikan nafkah (baik lahir maupun bathin)". Maka, jika kewajiban mencari nafkah dilakukan seorang istri, hal itu telah bertentangan dengan ayat tersebut, sebab istri itu lebih baik diam di rumah mengurusi anak dan rumah.

Lebih lanjut K.H Hasan mengatakan, bahwa di dalam kitab Nasoihul 'Ibad dikatakan: "Umar bin Khattab pernah dimarahi oleh istrinya tapi beliau malah diam. kenapa beliau diam? karena dia merasa bahwa pekerjaan yang seharusnya dia lakukan justru malah dilakukan oleh istrinya seperti: mengurus anak, mencuci, menyetrika baju. Maka ketika istrinya marah, Umar bin Khattab hanya diam, sebab dia merasa betapa istrinya telah membantunya. Padahal semua itu (mencuci, menyetrika) adalah kewajiban suami.

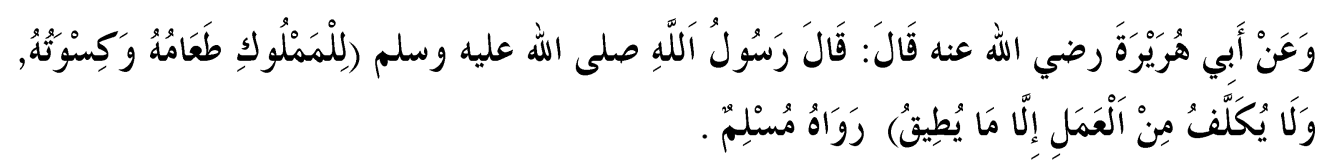

Dari Abu Hurairah bahwa Rasulullah Shallallaahu 'alaihi wa Sallam bersabda: "Hamba yang dimiliki wajib diberi makan dan pakaian, dan tidak dibebani pekerjaan kecuali yang ia mampu (Riwayat Muslim).

Kemudian, jika sekarang semua kewajiban itu dilakukan istri termasuk mencari nafkah sementara suami malah diam, maka jelas hal itu tidak sesuai dengan ayat di atas sebab Allah telah melebihkan derajat lakilaki dibanding wanita, salah satunya karena laki-laki mempunyai kewajiban untuk memberi nafkah.

Menurutnya, jika kewajiban itu terbalik, istri yang bekerja dan mencari nafkah, maka kedudukan suami sebagai pemimpin sudah tidak ada karena kewajiban telah dipikul oleh istrinya. Adapun istri yang bekerja dan 
memenuhi kebutuhan rumah tangganya, hal tersebut tidak dapat dikatakan sebagai nafkah karena nafkah adalah pemberian dari suami terhadap istrinya, yang diberikan istri terhadap keluarganya tersebut dapat dikatakan hanya sebagai suatu kebaikan atau juga shadaqah saja, sebab bagi istri tidak ada kewajiban untuk mencari nafkah (Hasil wawancara tanggal 30 September 2016).

Selain itu, beliau menjelaskan bahwa masalah di atas juga berkaitan dengan sebuah hadis Nabi:

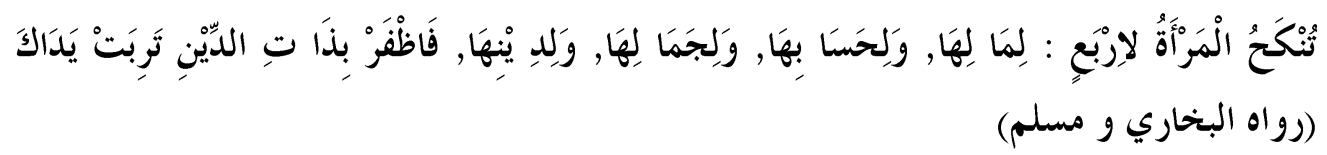

Nikahilah wanita itu karena empat hal, yakni: karena hartanya, keturunannya, kecantikannya, dan agamanya. Pilihlah wanita yang baik agamanya, niscaya engkau akan selamat (Al-Asqalani, 1997, no 997:450 (H.R. Bukhari dan Muslim).

Dalam menafsirkan hadits tersebut, menurutnya sebenarnya hadits itu tidak hanya laki-laki dalam memilih calon istri, akan tetapi berlaku juga bagi seorang wanita dalam memilih calon suami. Dalam hadist tersebut terdapat kata "pilihlah karena hartanya", hal itu mengisyaratkan bahwa harta itu memang penting dalam menjalani kehidupan rumah tangga. Dan tidak hanya itu, dalam sebuah pernikahan harus terdapat keseimbangan (kesekufuan) antara suami dan istri dalam segala hal agar tidak terjadi ketimpangan dalam pelaksanaan hak dan kewajiban antara keduanya (Hasil wawancara tanggal 30 September 2016).

Kemudian, jika posisi suami dalam keadaan fisik masih sehat tetapi tidak mau berusaha dan istri yang malah bekerja, jelas suami berdosa karena meninggalkan kewajibannya. Akan tetapi, jika keadaan suami yang bekerja itu karena keadaanya sudah tidak memungkinkan untuk bekerja (ada udzur syara'), maka suami tidaklah berdosa. Dalam keadaan itu, istri yang harus berusaha dan bekerja untuk memenuhi kebutuhan keluarga, karena keadaan seperti itu menjadi darurat, namun bekerjanya istri harus tetap dengan izin suaminya. Tapi, dalam keadaan suami yang mengalami udzur syara' pun jika kelamaan menjadi merasa keenakan dan membiarkan istrinya yang menanggung kewajibannya untuk mencari nafkah, maka suaminya berdosa walaupun istrinya merasa ikhlas untuk bekerja. Sebab, bagaimana pun suami tidak boleh lari dari tanggung jawabnya dalam mencari nafkah (Hasil wawancara tanggal 01 Oktober 2016).

K.H Hasan mengatakan dalam sebuah hadist bahwa: "ketika seekor burung keluar dari sarangnya, dia dalam keadaan lapar, namun ketika sore hari dia pulang dari pencariannya, dia dalam keadaan kenyang". Menurut penafsiran beliau terhadap hadist tersebut mengisyaratkan bahwa seorang 
suami wajib keluar rumah untuk mencari nafkah dan tidak boleh bermalasmalasan, karena Allah akan memberikan rezeki bagi orang yang mau berusaha. Walaupun istri merasa ikhlas bekerja ketika suaminya pengangguran, namun suami tetap akan diminta pertanggung jawaban di akhirat kelak sebagi pemimpin keluarga yang berkewajiban mencari nafkah. Beliau berdalil dengan mengutip hadis Nabi:

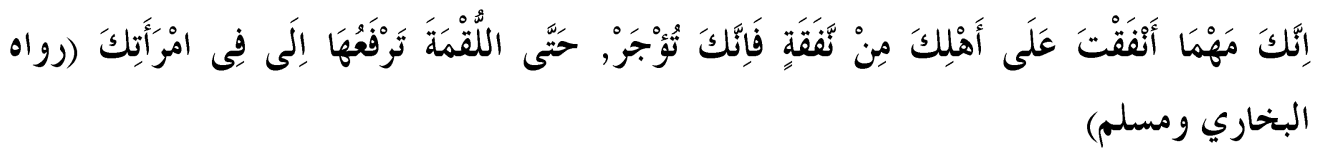

Apapun yang engkau berikan berupa suatu nafkah kepada keluargamu, maka engkau diberi pahala, hingga sampai sesuap makanan yang engkau masukan kemulut istrimu (H.R Bukhari dan Muslim).

Adapun jika keadaan suami yang pengangguran dan tidak mau berusaha untuk bekerja, maka menurut penuturan beliau istri memiliki dua pilihan. Pertama, apakah istri akan tetap bersabar dalam keadaan suami pengangguran? Kedua, apakah istri akan mengajukan gugat cerai? karena di dalam ta'lik talak dikatakan, jika suami tidak memberikan nafkah (lahir atau batin) dan istri tidak ridho, maka dia istri boleh mengajukan gugat cerai kepada suaminya sebab nafkah merupakan hak istri yang wajib di penuhi oleh suami. (Hasil wawancara tanggal 02 Oktober 2016).

Adapun Bapak Ustadz Didi Rosadi, disamping sebagai Mubaligh dan ia juga sebagai anggota MUI Desa Karangampel, memiliki pendapat mengenai wanita mencari nafkah lebih melihat dari segi keadaan yang mempengaruhi terjadinya hal tersebut. Menurutnya, hal itu dapat terjadi karena banyaknya pengaruh yang datang dari budaya barat melalui berbagai media yang menimbulkan adanya istilah gender yang seolah-olah ingin mempersamakan kedudukan antara laki-laki dan perempuan yang kemudian menjadi suatu gaya hidup, serta adanya tekanan ekonomi dalam rumah tangga sehingga di zaman sekarang itu banyak para istri yang bekerja di luar (berkarir) dengan bebas (Hasil Wawancara tanggal 02 Oktober 2016).

Namun, terlepas dari pengaruh tersebut, harus diketahui keadaan yang sebenarnya yang menyebabkan seorang istri mencari nafkah untuk keluarga. Sebab, pada perinsipnya kewajiban mencari nafkah dibebankan pada suami sebagaimana yang telah diperintahkan oleh syara' ketika menikah harus membayar mahar kepada istri yang mana hal tersebut mengisyaratkan bahwa suami wajib memberikan nafkah karena kedudukanya sebagai kepala keluarga. Sebagimana firman Allah, "Kaum laki-laki itu adalah pemimpin bagi kaum wanita, oleh karena allah telah melebihkan sebahagian mereka (laki-laki) atas sebahagian yang lain (wanita), dan karena mereka (laki-laki) telah menafkahkan sebahagian dari harta mereka (Q.S. An-Nisa, 04:34). 
Ayat tersebut diatas, menjelaskan bahwa suami adalah pemimpin bagi istrinya. Akan tetapi, dengan banyaknya pengaruh-pengaruh dari budaya barat tadi, dan juga tekanan ekonomi serta kebutuhan-kebutuhan yang semakin menghimpit, maka menyebabkan pergeseran nilai dan pola hidup para wanita di zaman sekarang ini yang pada akhirnya dalam keadaan tertentu mengharuskan istri untuk mencari nafkah (Hasil wawancara Tanggal 03 Oktober 2016).

Namun, dalam keadaan lain, ketika suami pengangguran dengan alasan sulit mendapatkan pekerjaan dan istri yang mencari nafkah, maka kasus seperti itu tidak dapat dijadikan pembenaran dalam beragumen. Dengan demikian, maka suami berdosa jika tidak melaksanakan kewajiban itu. Sebab, jika seandainya pun istri mencari nafkah hanya bersifat membantu suami yang di nilai sebagai kebaikan istri saja bukan harus mengambil alih tanggung jawab suami. Dalam keadaan bagaimana pun, suami harus melangkahkan kaki untuk berusaha. Bahkan dengan mengutip sebuah hadist Nabi beliau mengatakan: "jika suami bekerja mencari nafkah sampai keadaan lelah dan lemas di sore hari, maka Allah akan memberikan ampunan untuknya." Dengan demikian, wajibnya mencari nafkah bagi suami tidak hanya menjadi tanggung jawabnya karena suami, akan tetapi sudah menjadi tuntutan agama yang harus dilaksanakan. Maka, dalam keadaan suami yang pengangguran karena malas, tidak dapat dibenarkan jika istri yang menjadi pencari nafkah. Bahkan jika kita melihat kembali pada aturan syara', seorang suami tidak boleh memperkerjakan istri semena-mena. Suami harus menyediakan pembantu untuk membantu istrinya mengurus rumah (bila suami kaya), karena pada dasarnya kewajiban istri lebih berat di bandingkan suami. Istri selain mengurus rumah, juga harus melayani suami, mengurus anak-anak, maka atas dasar itulah kewajiban nafkah dibebankan kepada suami bukan kepada istri (Hasil wawancara tanggal 03 Oktober 2016).

Jika keadaan suami yang tidak bekerja dikarenakan udzur syara' seperti lumpuh, lanjut usia dan sakit yang tidak ada harapan sembuh lagi, hal itu akan berbeda masalahnya. Dalam posisi seperti itu, jika istri yang kemudian mengambil alih untuk mencari nafkah maka dibolehkan saja dan suami pun tidak berdosa. Akan tetapi, bukan berati membebaskan, menghalalkan (merubah hukum) suami untuk tidak berusaha, namun hal itu dalam keadaan ألضَُّوْرَاتُ تُبَيْحُ الْمَحْظُوْرَاتِ (keadaan darurat membolehkan hal-hal yang terlarang). Karena bagaimana pun, syari'at telah menetapkaan kewajiban nafkah adalah menjadi tanggung jawab suami. Sebagaimana dalam hadist yang diriwayatkan oleh Abu Daud dari Mu,awiyah bin Haidah, ia menuturkan: "aku bertanya ya Rasulullah, apa hak istri salah seorang dari kami terhadapnya ? Beliau menjawab: 


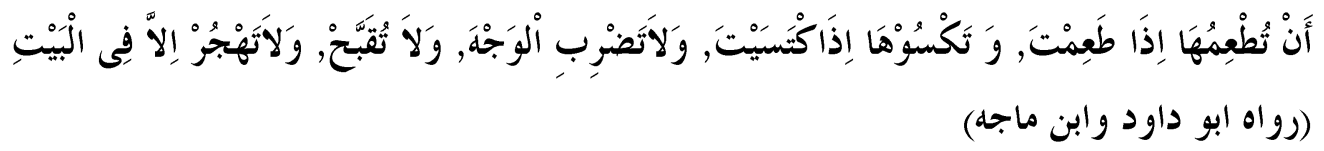

(Yaitu) engkau memberi makan kepadanya ketika engkau makan, dan memberi pakaian kepadanya ketika engkau berpakaian. Tidak memukul wajahnya, tidak mencacinya dan tidak pula mengucilkanya, kecuali di dalam rumah (H.R Abu Dawud dan Ibnu Majah).

Jika, dalam kondisi seperti yang telah dijelaskan diatas, maka istri dibolehkan bekerja tetapi harus memiliki batasa-batasan serta izin dari suaminya. Menurutnya, tidak hanya menjadi beban istri saja, namun harus ada peran serta (campur tangan) dari pemerintah untuk membantu keluarga yang keadaan ekonominya sulit (Hasil wawanacara tanggal 05 Oktober 2016).

Adapun bapak K.H. Endang Samsudin, disamping sebagai Mubaligh dan ia juga sebagi anggota MUI Desa Karangampel, memiliki pendapat masalah wanita yang mencari nafkah itu harus dilihat terlebih dahulu bagaimana kondisi suami istri itu yang sesungguhnya seperti apa. Jika seandainya benar-benar dalam keadaan darurat, dalam pengertian kondisi suaminya itu betul-betul tidak dapat mencari nafkah (karena udzur syara') maka hal tersebut akan termasuk pada "keadaan yang darurat membolehkan pada hal-hal terlarang" ألضَّرُوْرَاتُ تبيح الخظظؤَات dan istri boeh mencari nafkah dengan batasan-batasan yang di bolehkan syara', seperti : istri bekerja memang atas izin suami dan untuk kepentingan keluarga, istri bisa menjaga dirinya ketika berada di luar rumah, serta pekerjaanya itu adalah pekerjaan yang halal. Tapi, jika seandainya tidak darurat dalam artian suami masih dapat berusaha akan tetapi suami malah diam di rumah dengan alasan sulit mendapatkan pekerjaan dan justru istri yang bekerja, dalam keadaan seperti itu suami berdosa. Sebab, Allah telah menjanjikan jika telah menikah maka rezekinya akan ditambah dan dimudahkan jika mau berusaha. Bahkan logika pun Allah akan memberikan jalan jika memang suaminya itu benar-benar mau berusaha karena kewajiban suami adalah mencari nafkah (Hasil wawancara tanggal 03 Oktober 2016).

Menurutnya, tanggung jawab suami dalam mencari nafkah tidak dapat alihkan pada istri sekalipun istri merasa ikhlas jika memang harus bekerja mencari nafkah. Dalam keadaan istri merasa ikhlas, memang boleh saja untuk bekerja, namun peran suami menjadi tidak maksimal dan seolaholah seperti mengabaikan kewajibanya. Ketiak istri yang berperan mencari nafkah untuk keluarga dan juga tetap mengurusi rumah, mengurusi anakanak serta melayani suami, kondisi seperti itu malah akan berpotensi menimbulkan kemadaratan. Diantaranya, istri lama-kelamaan akan kurang khidmat pada suaminya karena dia merasa yang telah menanggung 
semuanya dan peran suami dirasa tidak ada (Hasil Wawancara tanggal 03 Oktober 2016).

Lebih lanjut K.H. Endang Samsudin menjelaskan, seorang istri harus menghormati suaminya jika ia melaksanakan kewajibannya dengan baik, salah satunya memberikan nafkah (lahir batin). Jika suami tidak memberikan nafkah justru malah digeser pada istrinya, maka tidak menutup kemungkinan istri akan merasa bahwa yang menjadi kepala keluarga itu adalah dirinya. Sehingga, begaimana pun keadaannya suami harus tetap berusaha untuk mencari nafkah, setidaknya harus memperlihatkan rasa tanggung jawabnya terhadap keluarga.

Istri yang bekerja mencari nafkah, sebenarnya apa yang dihasilkannya dari bekerja dan diberikan kepada keluarganya itu tidak dapat dikatakan sebagai nafkah, karena tidak ada kewajiban istri untuk mencari nafkah. Namun, hal itu merupakan suatu kebaikan dan khidmat istri terhadap keluarga karena dalam posisi itu, istri selain mancari nafkah juga harus tetap melaksanakan kewajibannya sebagi istri mengurus anak, melayani suami dan mengurus rumah. Ketika istri yang berperan mancari nafkah dan suami justru pengangguran, maka dalam posisi itu, istri memiliki pilihan tetap bersabar atau menggugat cerai suaminya. Karena di dalam ta'liq talak terdapat ketentuan jika suami sudah lama tidak memberikan nafkah, maka istri boleh menggugat cerai. Dari pernyataan tersebut, mengisyaratkan bahwa suami wajib mencari nafkah dan bukan kewajiban seorang istri karena suami adalah pemimpin dalam rumah tangganya.

Hal ini di dasari dengan firman Allah, "Kaum laki-laki itu adalah pemimpin bagi kaum wanita, oleh karena allah telah melebihkan sebahagian mereka (laki-laki) atas sebahagian yang lain (wanita), dan karena mereka (laki-laki) telah menafkahkan sebahagian dari harta mereka (Q.S An-Nisa, $4: 34)$.

Menurut K.H Endang Samsudin ada hadits yang berkaitan dengan kepemimpinan suami dan tanggung jawab nafkah keluarga, sebagaimana hadis Nabi sebagai berikut:

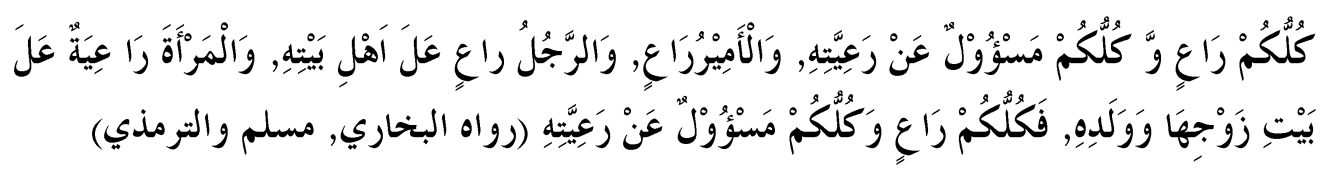

Setiap kalian adalah pemimpin dan setiap pemimpim akan ditanya tentang kepemimpinannya. Penguasa adalah pemimpin, seorang laki-laki adalah pemimpin atas keluarganya, wanita adalah pemimpin atas rumah suaminya dan anak-anaknya. Jadi, setiap kalian adalah pemimpin dan setiap kalian akan ditanya tengtang kepemimpinannya (H.R. Bukhari, Muslim dan Tirmidzi),(wawancara tanggal 08 Oktober). 
Adapun Bapak K.H Endin Rosidin (sebagai Ketua MUI Desa Karangampel dan juga sebagi pimpinan Pondok Pesantren Al-Istiqomah), mengatakan dalam rumah tangga suami istri itu:

1) Harus saling ta'awun (tolong menolong) yaitu dalam hal kebaikan sebagaimana Allah berfirman, "Dan tolong-menolonglah kamu dalam (mengerjakan) kebajikan dan takwa, dan jangan tolong-menolong dalam berbuat dosa dan pelanggaran (Q.S. Al-Maidah, 05: 02).

2) Dalam hal nafkah, itu merupakan kewajiban mutlak bagi suami dan apabila suami tidak mampu memberikan nafkah kepada keluarga, maka suami berdosa dan dianggap meninggalkan kewajibannya.

Adapun suami dalam keadaan sakit, pengalamannya terbatas sehingga sulit untuk mendapatkan pekerjaan, kemudian istri akhirnya harus bekerja, maka disana posisi istri hanya membantu suami dan kehidupan rumah tangganya. Oleh karena yang bekerja adalah istri, maka yang berhak mengelola adalah istri dan karena sifatnya juga membantu, maka beban itu tidak hanya di tanggung oleh istri, akan tetapi suami juga harus tetap berusaha. Dan apa yang telah dilakukan oleh istri itu adalah suatu amal kebaikan yang bernilai pahala. Sebagaimana dalam firman Allah SWT, "Barangsiapa yang mengerjakan amal saleh, baik laki-laki maupun perempuan dalam Keadaan beriman, Maka Sesungguhnya akan Kami berikan kepadanya kehidupan yang baik dan Sesungguhnya akan Kami beri Balasan kepada mereka dengan pahala yang lebih baik dari apa yang telah mereka kerjakan (Q.S.An-Nahl, 16:97).

3) Istri menjadi pencari nafkah itu harus dalam kondisi normal, dalam artian harkat kewanitaanya terjaga, auratnya tertutup dan tidak melanggar syara', maka dalam koridor tertentu hukumnya bagi istri mubah (boleh). Tapi, jika kehormatannya dikhawatirkan terganggu, auratnya terbuka maka haram bagi istri untuk bekerja di luar.

Lebih lanjut beliau mengatakan, dalam keadaan apapun jika istri bekerja mencari nafkah (baik karena suaminya pengangguran atau sakit), hukumnya bagi istri adalah wenang atau mubah saja tidak sampai pada wajib, namun harus tetap dalam koridor aturan syara' atau tidak melanggar haddu-syar'i. Sebab, dalam sebuah hadis dikatakan: "Apabila ada perempuan meninggalkan rumah lebih dari satu hari satu malam, maka harus didampingi oleh muhrim." Pengertian muhrim disini yaitu yang bisa menjaga kehormatan.

Seoarang suami yang mendapatkan udzur syara' sehingga tidak mampu lagi bekerja, bukan berarti membebaskan suami dari tanggung jawabnya dalam mencari nafkah, akan tetapi karena ada kebaikan istri yang rela untuk bekerja sehingga kebutuhan rumah tangga di penuhi oleh istri. Tapi, bukan semuanya di hendle oleh istri, sebab dalam hukum fiqh dikatakan kewajiban utama istri adalah untuk meladeni suami di kamar, 
oleh karena itu suami juga harus tetap berupaya mandiri. Jika suami suami tidak melakukan upaya atau usaha apapun, maka suami berdosa. Berdasarkan dengan firman Allah SWT, "Kaum laki-laki itu adalah pemimpin bagi kaum wanita, oleh karena allah telah melebihkan sebahagian mereka (laki-laki) atas sebahagian yang lain (wanita), dan karena mereka (laki-laki) telah menafkahkan sebahagian dari harta mereka (Q.S. An-Nisa, 04:34).

Dengan melihat ayat tersebut, karena laki-laki adalah pemimpin bagi wanita, itu berati tanggung jawab untuk memenuhi kebutuhan istri adalah kewajiban suami. Apalagi dalam ayat tersebut juga dikatakan bahwa kaum laki-laki dilebihkan di banding wanita. Hal itu mengindikasikan karena suami memberikan mahar dan juga nafkah kepada istrinya.

Dan mengutip sebuah hadis Nabi:

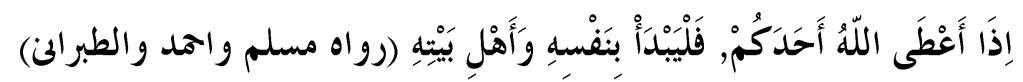

Jika Allah memberikan kehakiman kepada salah seorang dari kalian, maka mulailah dengan dirinya sendiri dan keluarganya (Muslim, tt, no 1822 (H.R. Muslim, Ahmad dan Thabrani). (wawancara tanggal 11 Oktober 2016).

a. Metode Ijtihad yang Digunakan Ulama Desa Karangampel mengenai Wanita sebagi Pencari Nafkah Utama dalam Kehidupan Rumah Tangga

Berdasarkan data-data yang di peroleh di lapangan dan hasil wawancara mengenai wanita sebagai pencari nafkah dalam kehidupan rumah tangga, ulama Desa Karangampel dengan cara langsung memahami ayat-ayat al-Qura'an dan as-Sunnah secara tekstual dan kontektual sesuai dengan pemahaman masing-masing berdasarkan pengkajian terhadap kitab kitab yang mereka pelajari ditambah penalaran yang mereka asumsikan dari hasil pembelajaran di pesantren, dengan mencurahkan seluruh kemampuannya dalam memahami makna demi makna dalam lafadz-lafadz ayat dan hadits-hadits tentang kewajiban suami istri khususnya nafkah. Dan didapat keterangan bahwasanya seorang wanita pencari nafkah dalam kehidupan rumah tangga, harus dilihat terlebih dahulu kondisi rumah tangganya yang sebenarnya. Jika kondisinya benar-benar darurat seperti keadaan suami pengangguran karena adanya udzur syara' maka dalam kondisi seperti itu, istri di bolehkan untuk bekerja di luar mencari nafkah dengan batasan dibolehkan syara'. Akan tetapi, jika suami pengangguran dengan alasan sulit mendapatkan pekerjaan kemudian malah istri yang berusaha, tentu suami berdosa karena tidak melaksnakan kewajibanya dengan baik.

Kewajiban suami mencari nafkah, karena mereka adalah pemimpin atau kepala rumah tangga dan Allah telah melebihkan mereka 
dibandingkan perempuan sebagaimana digambarkan dalam surat an-Nisa Ayat 34 yaitu "Memberiakan nafkah dari sebagian harta mereka." Mereka mengambil istinbath hukum berdasarkan al-Qur'an dan as- Sunnah, bahwa suami wajib mencari nafkah untuk keluarga (anak dan istri). Oleh karena itu, ketika keadaan rumah tangga suami istri menghadapi keadaan yang mengharuskan istri untuk berperan mencari nafkah, maka hal itu menjadi kondisi darurat yang harus di pilih istri demi mempertahankan rumah tangganya. Dan para ulama ini hanya membahas sedikit mengenai kaidahkaidah fiqih yang mereka jadikan hujjah yaitu: "Keadaan darurat membolehkan hal yang terlarang", dalam artian, karena seorang istri menurut hukum asal syara' harus tinggal di rumah karena dia adalah pemimpin dalam rumah suaminya dan tidak ada kewajiban baginya mencari nafkah sementara dalam keadaan darurat istri menjadi di bolehkan untuk bekerja dan mencari nafkah.

\section{b. Analisis tentang Wanita Sebagai Pencari Nafkah Utama Dalam Kehidupan Rumah Tangga}

Berdasarkan data yang diperoleh di lapangan, bahwasanya setiap keluarga baik dari lingkungan terpelajar maupun tidak, dapat dipastikan akan menghadapi masalah yang beragam dan berbeda yang dapat menggoyah fondasi keluarga. Masalah yang bermacam-macam bisa jadi muncul karena faktor yang berasal dari luar maupun dari dirinya sendiri. Kini, sejalan dengan perubahan zaman, yang diikuti dengan perkembangan budaya dan peradaban manusia yang semakin kompleks, setiap keluarga akan menghadapi tantangan yang tidak ringan.

Di dalam Islam terdapat landasan penting tentang bagaimana menciptakan dan melanggengkan keluarga. Tuntutan sederhana untuk membangun keluarga yang baik adalah masin-masing anggota keluarga (suami, istri dan anak) mengetahui, menyadari, dan melaksanakan hak dan kewajibannya yang didasari dengan nilai-nilai agama. Semua anggota keluarga khususnya suami-istri, harus mematuhi dan merealisasikan hak dan kewajibannya dengan baik dalam kehidupan sehari-hari. Bahkan secara psikologis, kesejahteraan atau kebahagiaan keluarga akan berkembang bila kebutuhan anggota keluarga terpenuhi. Akan tetapi, tidak sedikit diantara suami istri lupa akan peran atau hak dan kewajibannya masing-masing.

Banyak fakta di zaman sekarang muncul suatu masalah bahwa seorang istri menjadi pencari nafkah untuk menghidupi keluarga. Bahkan dalam penelitian yang saya lakukan, ditemukan kasus-kasus yang mana istri sebagai pencari nafkah sementara suami pengangguran dan diam di rumah. Jika sudah demikian, lalu di mana letak kepemimpinan seorang lakilaki sebagai suami (kepala rumah tangga) ? Padahal dengan jelas Allah berfirman di dalam surat an-Nisa: 34, "Kaum laki-laki itu adalah pemimpin bagi kaum wanita, oleh karena allah telah melebihkan sebahagian mereka 
(laki-laki) atas sebahagian yang lain (wanita), dan karena mereka (laki-laki) telah menafkahkan sebahagian dari harta mereka (Q.S. An-Nisa, 04:34).

Menurut ulama Desa Karangampel melihat konteks ayat tersebut bahwa yang dimaksud dengan laki-laki sebagi pemimpin bagi kaum wanita yaitu dalam hal mendidik, memimpin dan mengingatkan jika terjadi penyimpangan. Sementara yang dimaksud dengan melebihkan laki-laki atas wanita yaitu karena suami memberikan mahar, memberikan nafkah dan mencukupi pangan keluarga. Sehingga, menurut ayat tersebut jika istri yang mencari nafkah, maka bertentangan dengan ayat tersebut.

Apabila ditelusuri pada masa Rasulullah, memang terlihat suatu gejala bahwa perempuan (istri) ada yang turut bekerja sebagai pedagang, pengusaha, guru dan lain-lain seperti Khadijah, Aisyah. Namun, meskipun demikan seorang perempuan tetap tidak boleh melupakan tugasnya sebagai istri dan ibu bagi anak-anaknya. Menurut ulama Desa Karangampel, bahwa ketika seorang istri menjadi pencari nafkah, harus terlebih dahulu dilihat bagaimana kondisi rumah tangga yang sebenarnya sehingga diketahui faktor yang menyebabkan hal itu terjadi. Mereka mengatakan, bahwa:

1. Jika istri yang bekerja mencari nafkah karena keadaan suami yang pengangguran dengan alasan sulit mendapatkan pekerjaan, maka posisi istri sebenarnya tidak ada kewajiban untuk mencari nafkah, karena sulitnya mendapatkan pekerjaan tidak bisa di jadikan sebagai pembenaran suami dalam beragumen. Sebab, suami masih bisa mengusahakan agar tidak menjadi pengangguran selama dia mau berusaha. Namun, jika memang istri ridho untuk bekerja, maka di bolehkan saja dengan syarat istri tidak melanggar aturan syara'. Akan tetapi, dalam posisi seperti itu, dikhawatirkan akan menimbulkan kemadharatan karena istri yang berperan mencari nafkah dan juga berperan di rumah, lama-kelamaan posisi suami sebagai kepala keluarga menjadi tidak ada sehingga istri akan merasa lebih tinggi posisinya dari suami. Olah karena itu, suami tidak dibenarkan untuk menjadikan sulitnya mendapatkan pekerjaan sebagai alasan baginya untuk tidak mencari nafkah. Dan keadaan yang demikian, tidak dapat dikatakan sebagai keadaan yang darurat yang menyebabkan istri harus bekerja. Sebab, istri hanya berkewajiban mengurusi segala urusan dalam rumah dan suami lah yang wajib bekerja di luar.

2. Jika istri yang bekerja karena keadaan suami udzur syara' seperti lumpuh atau sakit yang tidak ada harapan lagi untuk sembuh, maka disana istri boleh (wenang) untuk bekerja kerena memang keadaannya itu darurat bukan karena suaminya malas, namun kebolehannya tidak sampai kepada wajib sebab nafkah merupakan kewajiban mutlak suami. Dalam kondisi seperti itu, memang keadaan darurat dan disana istri boleh mengambil peran untuk membantu suami dan menyelamatkan 
kehidupan rumah tangganya. Karena dalam kehidupan rumah tangga, suami istri harus saling ta'awun (tolong-menolong). Sebagaimana firman Allah SWT, "Dan tolong-menolonglah kamu dalam (mengerjakan) kebajikan dan takwa, dan jangan tolong-menolong dalam berbuat dosa (Q.S. Al-Maidah 05:02).

Mengenai kebolehan istri untuk bekerja baik dalam keadaan suami yang udzur syara' ataupun pengangguran (malas), ulama Desa Karangampel menjelaskan kondisi tersebut dalam keadaan " الضرورات تبيح "الخظو رات", yaitu keadaan darurat membolehkan hal-hal yang terlarang, dalam artian ketika seoarang istri menurut hukum syara' harus berada di rumah kemudian dalam keadaan yang darurat, ia dibolehkan untuk bekerja di luar. Dan bolehnya istri bekerja di luar harus dengan syarat-syarat: istri dapat menjaga diri dan kehormatannya, auratnya tertutup, pekerjaanya halal dan untuk kepentingan keluarga, adanya izin dari suami, istri yang melakukannya juga ridho dan tidak melanggar aturan syara', maka jika tidak dalam keadaan darurat, kewajiban mencari nafkah menjadi tanggung jawab suami sepenuhnya terhadap istri. Sebagaimana dalam hadis Nabi:

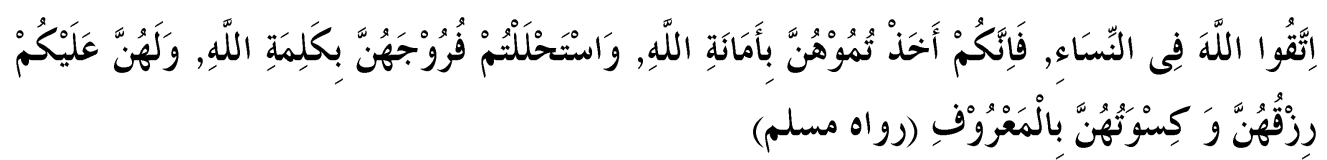

Bertakwalah kepada Allah dalam hal perihal wanita. Karena sesungguhnya kalian mengambil mereka dengan amanat Allah dan dihalalkan atas kalian kemaluan mereka dengan kalimat Allah. Maka hak atas kalian adalah memberi nafkah dan pakaian kepada mereka dengan cara yang ma'ruf (H.R. Muslim).

Dari penjelasan di atas, mereka menilai bahwa Islam menjadikan lakilaki sebagai kepala keluarga sebab dipundaknyalah tanggung jawab utama nafkah lahir bathin keluarga, karena pada dasarnya istri berkewajiban untuk mengurusi urusan di dalam rumah bukan di luar rumah. sebagaimana firman Allah, "Dan hendaklah kamu tetap di rumahmu dan janganlah kamu berhias dan bertingkah laku seperti orang-orang Jahiliyah yang dahulu (Q.S. Al-Ahzab, 33:33).

Ayat tersebut menurut penafsiran mereka bahwa istri harus berada di rumah dan dibolehkan ke luar rumah jika memang ada keperluan syara saja. Sehingga, kebolehan istri untuk bekerja di luar hanya dalam keadaan tertentu yang benar-benar darurat. Meskipun Islam tidak melarang seorang istri untuk berkarir, namun ketika istri bekerja di luar tanpa adanya alasan dan kondisi yang darurat, maka akan lebih banyak madaratnya bagi istri sendiri. Di antaranya, jika istri yang bekerja di luar selain mencari nafkah, juga harus tetap mengurusi rumah, mengurusi anak-anak dan melayani suami, lama-kelamaan istri akan merasa dia menjadi kepala keluarga, 
sehingga rasa khidmat terhadap suami pun tidak menutup kemungkinan akan tidak ada. Apalagi dengan adanya pemahaman gender di zaman sekarang ini, semakin memperkuat dan melanggengkan nila-nilai sosial budaya yang lama-kelamaan menjadikan gaya hidup bagi wanita untuk bekerja demi kelangsungan hidup keluarga. Oleh kerena itu, jika keadaan ekonomi keluarga telah tercukupi oleh suami, maka lebih baik bagi istri untuk tetap di rumah.

Berdasarkan penjelasan di atas, dalam memahami masalah wanita sebagai pencari nafkah utama dalam kehidupan rumah tangga K.H Hasan menggunakan al-Qur'an dan as-Sunnah sebagai landasan hukum yang dipegangya serta tidak memberikan keringanan bagi istri untuk mencari nafkah karena menurutnya semua sudah tertera jelas dalam al-Qur'an dan as-Sunnah.

Setelah memahmi penjelasan di atas ustadz Didi Rosadi mengunakan al-Qur'an dan as-Sunnah dalam memahmi masalah wanita sebagai pencari nafkah utama dalam kehidupan rumah tangga, serta menggunakan kaidah hukum islam tentang keadaan darurat yang membolehkan hal yang terlarang الضرورات تبيح الخظورات

Dalam memahami masalah wanita sebagai pencari nafkah utama dalam kehidupan rumah tangga, K.H. Endang Samsudin berpegang teguh pada al-Qur'an dan as-Sunnah yang menjadi sumber hukum Islam yang utama. Terlepas dari jabatan sebagai anggota mui Desa Karangampel, dia juga mengunakan ijma ulama di Desa Karangampel sebagai dasar bagi masalah ini.

Pandangan K.H. Endin Rosidin dalam masalah wanita sebagai pencari nafkah utama dalam kehidupan rumah tangga berdasar pada al-Qur'an dan as-Sunnah. Serta menggunakan metode ijtihad maslahah mursalah karena memberikan alasan ta'awun (saling tolong menolong) yang menjadi kemaslahatan bagi keduanya.

Dalam mengistinbathkan hukum, para ulama menggunakan al-Qur'an dan as-Sunnah, bahwa suami wajib mencari nafkah untuk keluarga (anak dan istri). Dan ketika keadaan rumah tangga suami istri menghadapi keadaan yang mengharuskan istri untuk berperan mencari nafkah, maka hal itu menjadi kondisi darurat yang harus di pilih istri demi mempertahankan rumah tangga. Itulah keagungan aturan Islam yang mengatur berbagai segi kehidupan manusia di antaranya dalam hal pelaksanaan hak dan kewajiban suami istri khususnya masalah pemenuhan nafkah keluarga.

\section{KESIMPULAN}


Setelah penulis memberikan pembahasan dari hasil penelitian mengenai pengambilan kewajiban memberi nafkah suami oleh istri, tentunya akan diakhiri beberapa kesimpulan supaya dapat di Tarik benang merah, yakni: (1) Bahwa berdasarkan hasil penelitian yang dilakukan di lapangan, fsaktor penyebab munculnya wanita segabai pencari nafkah berdasarkan hasil observasi dan wawancara langsung terhadap objek yang dituju, diantaranya: pertama, karena suaminya pengangguran dengan alasan sulit mendapatkan pekerjaan. Kedua, karena paktor usia yang sudah tua. (2) Menurut ulama Desa Karangampel, penilaian terhadap wanita sebagi pencari nafkah itu harus dilihat keadaan yang sebenarnya, dan hal itu dilihat dari dua kondisi, yaitu: pertama, jika istri yang bekerja mencari nafkah kerena keadaan suami yang pengangguran dengan alasan sulit mendapatkan pekerjaan, maka posisi istri sebenarnya tidak ada keawajiban untuk mencari nafkah, karena keadaan yang demikian tidak dapat dikatakan sebagai keadaan darurat yang menyebabkan istri harus bekerja. Namun, jika memang istri ridho untuk bekerja, maka dibolehkan saja dengan syarat tidak melanggar aturan syara'. Kedua, jika istri yang bekerja kerena keadaan suami suami udzur syara' seperti lumpuh atau sakit yang tidak ada harapan lagi untuk sembuh, maka disana istri boleh (wenang) untuk bekerja karena memang keduanya itu darurat karena bukan suaminya malas, namun kebolehannya tidak sampai kepada wajib sebab nafkah merupakan kewajiban mutlak suami. Dalam kondisi seperti itu, memang keadaanya darurat dan disana istri boleh menganbil peran untuk membantu suami dan menyelamatkan kehidupan rumah tangganya. (3) para ulama Desa Karangampel dalam metode istinbath hukum, menggunakan al-Qura'an dan as-Sunnah yang mana telah diatur dengan jelas oleh keduanya serta menggunakan kaidah hukum islam tentang الضرورات تبيح keadaan darurat yang membolehkan hal yang terlarang yaitu الخظورات

\section{DAFTAR PUSTAKA}

Alhamdani. (1985). Risalah Nikah. Pustaka Amani, Jakarta.

Fillah, Salim A. Agar Bidadari Cemburu Padamu. Yogyakarta: Pro-u media, 2006.

LPP IAID. (2001). Panduan Penyusunan Penelitian di Lingkungan Institut Agama Islam Darussalam, Ciamis.

Mahalli, A. Mujab. Menikahlah, Engkau Menjadi Kaya.Yogyakarta: Mitra Pustaka, 2008.

Muhammad, Husein, Figh Perempuan, Yogyakarta: LKiS, 2001

Ramulyo, Idris. Hukum Perkawinan Islam. Jakarta: Bumi Aksara, 2004. 
Sayyid sabiq, terjemah fiqih sunnah, Bandung:Al-Ma'arif, 1981.

Sumadi (2017) “The Development Of Feminist Epistemology In Islamic Studies In Indonesian University, A Case Study Of Akhwal Syaikhsiyah Study Program Of Darussalam Islamic Institute, Ciamis West Java" Jurnal Epistemé, Vol. 12, No. 1, Juni 2017, hal 232-259

Syarifuddin, Amir. Edisi 1, cetakan ke 4, hukum perkawinan Islam di Indonesia:antara fiqih munakahat dan Undang-undang Perkawinan. Jakarta: Kencana Prenada Media Grup, 2009.

Usamah, Abu Hafsh. (2006). Panduan Lengkap NIkah. Pustaka Ibnu Katsir, Bogor.

Uwaidah, Syaikh Kamil Muhammad. Fiqih Wanita. Jakarta: Pustaka AlKautsar, 2006. 
